\title{
Editorial
}

\section{Acta Dermatovenerologica Alpina, Pannonica et Adriatica accepted for coverage in Thomson Reuters' Emerging Sources Citation Index (ESCl)}

\author{
Mario Poljak ${ }^{1,2}$, Jovan Miljković3 ${ }^{3}$ Tina Triglav ${ }^{1,4}$
}

\begin{abstract}
Acta Dermatovenerologica Alpina, Pannonica et Adriatica (Acta Dermatovenerol APA) is the leading journal in dermatology and sexually transmitted infections in the region. Several important steps were taken during the last 25 years to improve the journal's quality, global visibility, and international impact. After a 1-year trial period, Thomson Reuters recently informed the editorial office that they had accepted Acta Dermatovenerol APA for coverage in Thomson Reuters' new index in the Web of Science Core Collection called the Emerging Sources Citation Index (ESCI). The coverage of Acta Dermatovenerol APA begins with the journal content published online in 2016; that is, from volume 25 onwards.
\end{abstract}

Received: 5 August 2016 | Returned for modification: 20 August 2016 | Accepted: 24 August 2016

The journal Acta Dermatovenerologica Alpina, Pannonica et Adriatica (Acta Dermatovenerol APA) was founded in 1992 in Ljubljana by Aleksej Kansky, who was also the journal's first editor-in-chief (1). Over the last 25 years, the journal and its editors experienced many challenges, as described in detail previously (2). In order to improve the journal's quality and establish its international recognition, several crucial steps were taken. The international profile of the journal significantly increased after 2000, when the journal implemented an online open access policy in addition to the printed version. Since then, the entire content of Acta Dermatovenerol APA has been freely available at the journal's website, http://www.acta-apa.org/.

A major accomplishment occurred in 2005, when the journal achieved full indexing status in Index Medicus / MEDLINE in addition to Biomedicina Slovenica and EMBASE / Excerpta Medica. Thus, from volume 14 onwards, the entire content of the journal has been included in PubMed, one of the most important bibliographic databases for medical journals. Coverage of the journal in PubMed significantly improved its international recognition and substantially boosted its citation rate (2).

After identifying several cases of plagiarism and duplicate publications leading to subsequent retractions (3), another major achievement was compulsory checking of the scientific integrity of all material submitted from June 2008 onward using the plagiarism-detection software Ithenticate (http://ithenticate.com/). In the last decade, plagiarism-detection software has allowed us to identify several cases of scientific misconduct. Unfortunately, we are still receiving manuscripts with an unacceptably high plagiarism score, leading to immediate rejection of more than one-fifth of the manuscripts submitted.

In 2012, we significantly redesigned the journal's structure and appearance in line with modern standards for a European journal. During 2014, we also fundamentally redesigned the journal's website, including digitization of all 699 contributions published since 1992, which are now freely available in full text format on the journal's archive website (http://www.acta-apa.org/journals/ acta-dermatovenerol-apa/archive).

Recently, several steps were taken to further increase the jour- nal's quality, including regular citation analyses (3), to attain the next important goal in the journal's development: official indexing of the journal in one of the three Thomson Reuters' Web of Science Core Collection flagship citation indexes, such as Science Citation Index Expanded (SCIE), and subsequently achieving the journal's first official impact factor. After a 1-year trial period, Thomson Reuters informed the editorial office in July 2016 that they had accepted Acta Dermatovenerol APA for coverage in Thomson Reuters' new index in the Web of Science Core Collection called the Emerging Sources Citation Index (ESCI). The coverage of Acta Dermatovenerol APA begins with the journal content published online in 2016; that is, from volume 25 onwards.

ESCI is a new edition in the Web of Science Core Collection launched in November 2015 (http://wokinfo.com/essays/journalselection-process/). This is a multidisciplinary citation index covering all areas of scholarly literature. The selection process for ESCI is related to the process applied to three Thomson Reuters' Web of Science Core Collection flagship citation indexes: SCIE, the Social Sciences Citation Index (SSCI), and the Arts \& Humanities Citation Index (AHCI). Journals accepted for coverage in ESCI must be peer reviewed, follow ethical publishing practices, meet Thomson Reuters' technical requirements, have English-language bibliographic information, and be recommended or requested by a scholarly audience of Web of Science users. Although some journals are selected directly into one or more Thomson Reuters' flagship citation indexes (SCIE, SSCI, AHCI), many other eligible journals are now being initially covered in ESCI. Journals initially covered in ESCI may be evaluated later for coverage in SCIE; however, coverage in ESCI does not guarantee eventual acceptance into SCIE. It is important to note that coverage in ESCI is entirely separate from coverage in SCIE and is never duplicated. Differently from journals indexed in SCIE, SSCI, and/or AHCI, Thomson Reuters does not calculate journal impact factor metrics for journals covered in ESCI. However, because ESCI is a true citation index, it is possible for users to track citation activity at the article and publication levels, and the citation activity for journals covered in ESCI will be used in the selection process for SCIE, SSCI, and AHCI. 
Thus, although we are not where we initially headed, we are proud that Thomson Reuters has accepted Acta Dermatovenerol $A P A$ for coverage in ESCI. In a year or two, when Thomson Reuters evaluates the latest Journal Citation Report data for our journal, the data may warrant the evaluation of the Acta Dermatovenerol APA for the desired SCIE. Thus, at this point, Acta Dermatovenerol
APA's destiny is completely in our hands: authors submitting their manuscripts to us as well as the journal's editors and reviewers. We ask all of our readers to strongly consider submitting their best original manuscripts, case reports, and reviews to Acta Dermatovenerol APA.

\section{References}

1. Miljković J. In memoriam: Aleksej Kansky, 1925-2015. Acta Dermatovenerol Alp Pannonica Adriat. 2015;24:65-6.

2. Oštrbenk A, Poljak M. Citation analysis of Acta Dermatovenerologica Alpina, Pannonica et Adriatica: 1992-2013. Acta Dermatovenerol Alp Pannonica Adriat. 2015;24:1-3.

3. Poljak M. Editorial: Acta Dermatovenerologica Alpina, Pannonica et Adriatica and scientific misconduct. Acta Dermatovenerol Alp Pannonica Adriat. 2009; 18:91-3. 